\title{
Investigation into boiler corrosion on the historic vessel SL Dolly
}

\section{A. Turnbull and M. J. Robinson*}

\begin{abstract}
When SL Dolly was recovered from Ullswater after being submerged for 67 years, the wrought iron boiler was found to have surprisingly little corrosion. This article describes the results of a project to investigate the reasons for this behaviour and determine whether it was a property of the wrought iron or a consequence of the lakebed environment. Weight loss measurements and electrochemical impedance spectroscopy were used to compare the corrosion rates of wrought iron and modern boiler steel exposed to tap water and samples of lake water and lakebed sediment. A corrosion probe was used to make in situ linear polarisation resistance measurements at the spot where Dolly sank. The corrosion rate of wrought iron on the lakebed was estimated to be in the range 0.018-0.030 $\mathrm{mm}_{\text {year }}{ }^{-1}$, which corresponds to a metal loss of $1.2-2.0 \mathrm{~mm}$ over the 67 year period; this metal loss is consistent with the condition of the boiler. The effects of microstructure, material composition and water chemistry are considered in detail, and it is concluded that the low oxygen content and the low concentration of dissolved solids in the lake water were the underlying causes of the observed corrosion behaviour.
\end{abstract}

Keywords: Boiler corrosion, Wrought iron, SL Dolly

\section{Introduction}

In 1962, an old steam launch was recovered from about $17 \mathrm{~m}$ of water at the bottom of Lake Ullswater in Cumbria. She was later identified as SL Dolly, built in about 1850, and having being restored to working order, she is thought to be the oldest mechanically powered vessel still operating with her original machinery. ${ }^{1}$

A remarkable part of this story is that when the launch was brought to the surface after 67 years on the lake bed, very little corrosion was found on the boiler. It was still possible to use a spanner to undo the retaining nuts holding the inspection cover. The boiler has the riveted wrought iron construction used in that period, and after some restoration work it was inspected and given approval to be put back into service. It was then steamed over the next 10 years, until it was eventually replaced with a new steel boiler, built to meet present day design requirements.

The question is, why did so little boiler corrosion occur during the time that the vessel was sunk? Wrought iron is known to possess excellent resistance to atmospheric corrosion, as demonstrated by the condition of the Delhi pillar, thought to date back to the 4th century AD. ${ }^{2}$ Similarly, Brunel's iron ship SS Great Britain, launched in 1843 and exposed for most of its life to seawater, has survived longer than might have been expected if the hull had been built of steel. Could the low

School of Industrial \& Manufacturing Science, Cranfield University, Bedford MK18 3AU, UK

*Corresponding author, email m.robinson@cranfield.ac.uk corrosion rate of Dolly's boiler be attributed to the inherent corrosion resistance of wrought iron? Indeed, is wrought iron really less prone to corrosion than the grades of steel used today?

A further explanation is that the thin layer of silt that had accumulated on the boiler may have been beneficial by reducing the concentration of dissolved oxygen at the metal surface. However, this silt could instead have been detrimental if active sulphate reducing bacteria had been present and the anaerobic conditions had favoured microbially influenced corrosion. ${ }^{3,4}$ Other possible explanations for the low corrosion rate are based on the chemical analysis of the lake water, which may contain either a low concentration of a naturally occurring corrosion inhibitor ${ }^{5}$ or heavy metal ions derived from the lead mining that had taken place in the area since the 17 th century. ${ }^{6}$

The aim of the project described in this article was to investigate each of these possible theories in detail. Corrosion rate measurements were carried out on wrought iron samples using a range of experimental techniques, both in the laboratory and in the field, in order to determine the most probable explanation for the low rate of corrosion that had been observed.

\section{Methods}

\section{Materials}

Rather than perform destructive tests on Dolly's boiler, two samples of wrought iron from a similar period were obtained on which to carry out the corrosion testing. The first of these (WI1) came from a source that was dated at 1850 , making it very close in age to the boiler. 


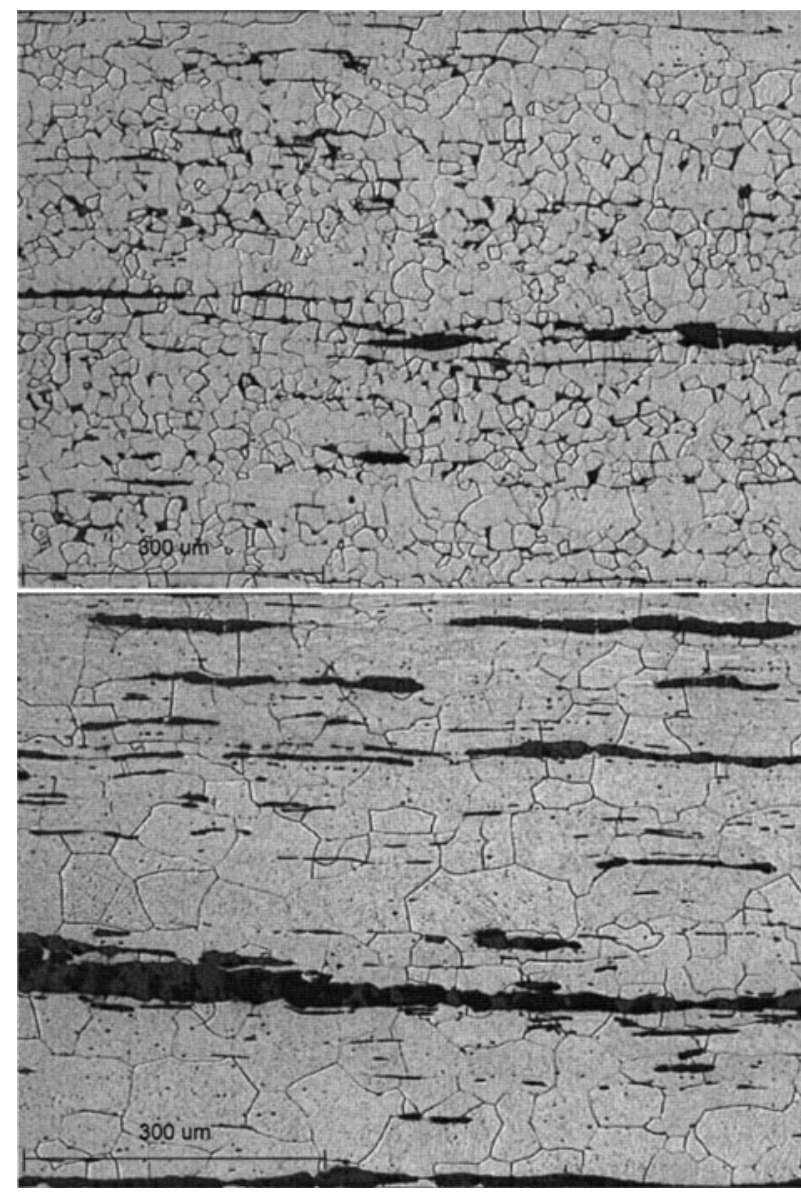

1 Typical longitudinal microstructures of WI1 and WI2 etched in $2 \%$ nital, showing equiaxed ferrite grain structures and elongated slag inclusions

The date of the second wrought iron sample (WI2) was unknown but from its source it is believed to have been produced earlier. In addition, a sample of ASTM A106 seamless carbon steel pipe (BS1), which is suitable for modern boiler construction, was tested for comparison.

The microstructures of the wrought iron samples were inhomogeneous and consisted of equiaxed ferrite grains with variable quantities of elongated slag inclusions, as shown in Fig. 1. In general, WI2 had larger ferrite grains and more extensive slag inclusions than WI1. The ferrite grains consisted of iron alone, with carbon and other elements being undetected; the slag inclusions were essentially iron oxide, with additional elements present in the case of WI1. The chemical compositions of the slag inclusions are shown in Table 1 and the analysis of the ASTM A106 steel is given in Table 2.

\section{Corrosion testing}

\section{Weight loss measurements}

Specimens were machined from the two wrought iron samples and A106 steel to give a surface area of $10 \mathrm{~cm}^{2}$ in each case. The specimens were degreased and

Table 1 Compositions of slag inclusions in WI1 and WI2

\%C $\% \mathrm{Ca} \% \mathrm{Fe} \% \mathrm{Mg} \% \mathrm{Mn} \% \mathrm{Mo} \% \mathrm{O} \% \mathrm{P}$ Si

$\begin{array}{lllllllll}\text { WI1 slag } & 0.35 & 38.9 & 1.18 & 0.76 & 0.39 & 54.0 & 2.31 & 2.13\end{array}$

$\begin{array}{llll}\text { WI2 slag } 47 \cdot 3 \quad 46.6 & 6 \cdot 1\end{array}$

preweighed to five decimal places of a gram and then immersed in Cranfield tap water in open topped $2 \mathrm{~L}$ troughs. An air bubbler was used to aerate one trough, and three replicate specimens of each material were positioned equidistantly around the bubbler. A second trough contained non-aerated tap water, such that oxygen was replenished by diffusion from the surface alone, and the same number of specimens was arranged uniformly around the centre. The third trough contained $1 \mathrm{~L}$ of tap water and $1 \mathrm{~L}$ of prewashed, fine silica sand $(250 \mu \mathrm{m}$ average particle size). The sand-water mixture was deaerated by purging with nitrogen for $10 \mathrm{~min}$, and the samples were buried in the sand to simulate the probable condition of Dolly's boiler when covered with lakebed sediment.

After exposure for 3 months, the specimens were taken out of the troughs and cleaned using a procedure based on ASTM-G1. ${ }^{7}$ Loose corrosion products were removed and the specimens were chemically cleaned in $30 \%$ hydrochloric acid containing $0.76 \mathrm{~g} \mathrm{~L}^{-1}$ of the inhibitor thiourea, and then reweighed. Uncorroded control specimens were also exposed to the cleaning solution to check the efficiency of the inhibitor and, where necessary, a correction was applied to the weight loss measurements.

\section{Electrochemical impedance spectroscopy (EIS)}

The aim of these experiments was to compare the corrosion behaviour of wrought iron exposed to Cranfield tap water and buried in sand, as used in the weight loss measurements, with the corrosion when immersed in water and sediment samples collected from Ullswater. The measurements were performed with a Solartron 1280 potentiostat and electrochemical interface using a pair of cylindrical wrought iron electrodes (WI1), each with a surface area of $10 \mathrm{~cm}^{2}$ and separated by a distance of $5 \mathrm{~mm}$.

\section{Linear polarisation resistance (LPR)}

Electrochemical measurements were carried out on Ullswater at the spot near Glenridding where Dolly sank so that the in situ corrosion behaviour could be compared with that observed in the laboratory. For practical reasons, battery operated linear polarisation resistance measurements (two point method) were used in preference to EIS. A weighted corrosion probe consisting of a pair of wrought iron electrodes (WI1), with the same configuration as used in the EIS experiments, was lowered from a boat and measurements were taken at $1 \mathrm{~m}$ intervals until the probe reached the lake bed. A dc of $6 \mu \mathrm{A}$ was passed between the two electrodes using a constant current source, and the potential difference between them (close to $10 \mathrm{mV}$ ) was recorded after a period of $2 \mathrm{~min}$. The current was then reversed, and after a further 2 min the potential difference was again recorded. The polarisation resistance $R_{\mathrm{p}}$ was calculated ${ }^{8}$ from the overall potential difference $\Delta V$ and the difference in the applied currents $\Delta I$

$$
R_{\mathrm{p}}=\Delta V / \Delta I
$$

The corrosion current density $i_{\text {corr }}$ was obtained from the relationship

$$
i_{\text {corr }}=B / R_{\mathrm{p}}
$$

where $B$ is the Stern Geary constant, taken to be $15 \mathrm{mV}$. 


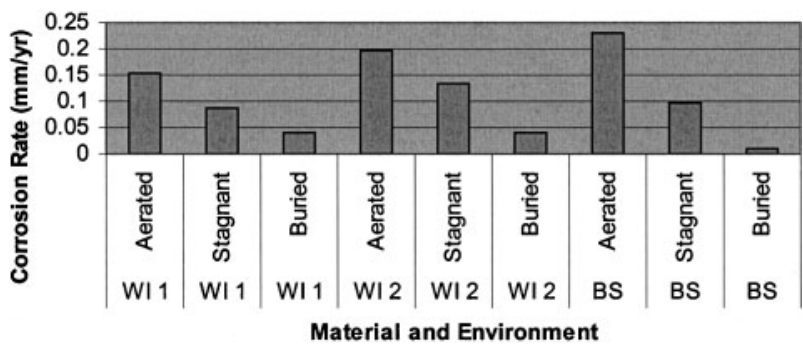

2 Mean corrosion rates of wrought iron (WI1 and WI2) and steel (BS) samples exposed to aerated and stagnant Cranfield tap water and buried in fine silica sand for 3 months

Finally, $i_{\text {corr }}$ was converted into corrosion rate using Faraday's law.

LPR measurements were also carried out in Cranfield tap water, with and without additions of fine sand, for further comparison with the EIS studies.

\section{Results and discussion}

\section{Weight loss}

The results of the weight loss measurements are shown in Fig. 2. It is clear that the oxygen content of the water had a large effect on the corrosion of all three materials, the rate in aerated water being approximately twice that in stagnant conditions. The values ranged between $0 \cdot 1$ and $0.2 \mathrm{~mm} \mathrm{year}^{-1}$ for specimens in quiescent and aerated conditions, and these correspond well with corrosion rates usually reported for steels in water. ${ }^{9}$ The corrosion rates of specimens buried in sand were substantially lower than those in the aerated or stagnant water.

The corrosion rates of the two wrought iron samples were similar and they did not differ substantially from those of the steel. While the corrosion rate of the steel in aerated water was higher than that of the two wrought iron samples, the rate for the buried steel was lower than those of the other two. From these results, it appears that the low corrosion rate of Dolly's boiler cannot be explained by wrought iron having an inherently lower

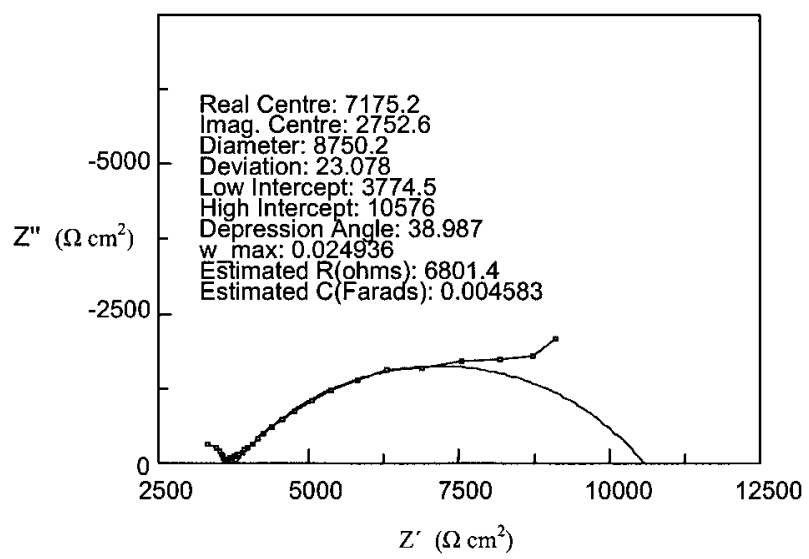

3 Impedance plot for WI1 in stagnant Cranfield tap water

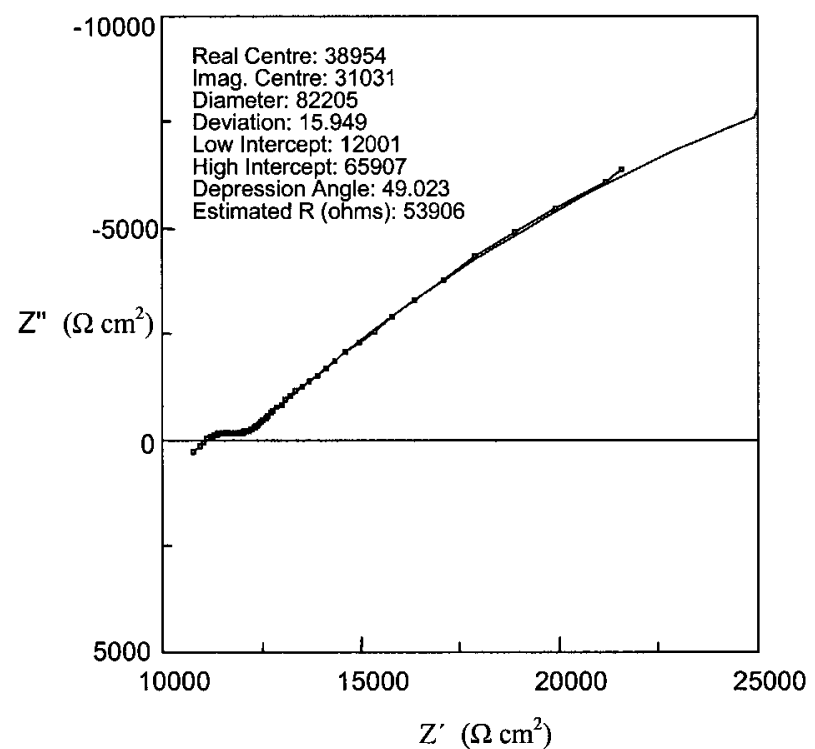

4 Impedance plot for WI1 exposed to Cranfield tap water and fine silica sand

corrosion rate than that normally associated with steel. The influence of slag inclusions on the corrosion behaviour of wrought iron is discussed in a later section.

\section{Electrochemical impedance spectroscopy}

The Nyquist plot $^{10}$ for WI1 displaying the in-phase $Z^{\prime}$ and out of phase $Z^{\prime \prime}$ components of impedance in stagnant Cranfield tap water is shown in Fig. 3. A semicircular curve was fitted to the data and its diameter was used to establish the charge transfer resistance $R_{\mathrm{t}}$, from which the corrosion rate was calculated using a corresponding relationship to that for the LPR method, given in equation (2). At the lowest measurement frequencies (approaching $1 \mathrm{mHz}$ ), the plot deviated from the semicircular form due to the controlling influence of oxygen transport to the metal surface. At the highest frequencies $(20 \mathrm{kHz}$ and below), there was some evidence of a surface film (small semicircle) and the intercept on the $x$-axis represents the resistance of the water between the two electrodes (solution resistance). In the case of the stagnant tap water, this resistance was in the order of $3800 \Omega$.

Figure 4 shows the corresponding impedance plot in tap water when the WI1 sample was buried in silica sand. The form of the plot was essentially the same as that in tap water alone but the solution resistance increased to $12000 \Omega$. This was caused by the sand acting as an incomplete non-conducting barrier such that the ionic path was limited to the water occupying the spaces between individual sand particles. Similarly, the charge transfer resistance increased from $6800 \Omega$ to $54000 \Omega$, indicating that there was a reduction in the corrosion rate of the wrought iron, approaching an order of magnitude. Again, this was the result of the sand acting as a partial barrier, restricting electrolyte access to the metal surface, together with the effects of dissolved oxygen depletion in the water.

Table 2 Analysis of ASTM A106 steel

\begin{tabular}{|c|c|c|c|c|c|c|c|c|c|c|c|}
\hline$\% \mathrm{C}$ & $\% M n$ & $\% \mathrm{Si}$ & $\% \mathrm{P}$ & $\% S$ & $\% \mathrm{Cr}$ & $\%$ Mo & $\% \mathrm{Ni}$ & $\% \mathrm{Cu}$ & $\% S n$ & $\% \mathrm{~V}$ & $\% \mathrm{Al}$ \\
\hline 0.142 & 0.643 & 0.242 & 0.007 & 0.005 & 0.127 & 0.028 & 0.102 & 0.195 & 0.014 & 0.000 & 0.030 \\
\hline
\end{tabular}




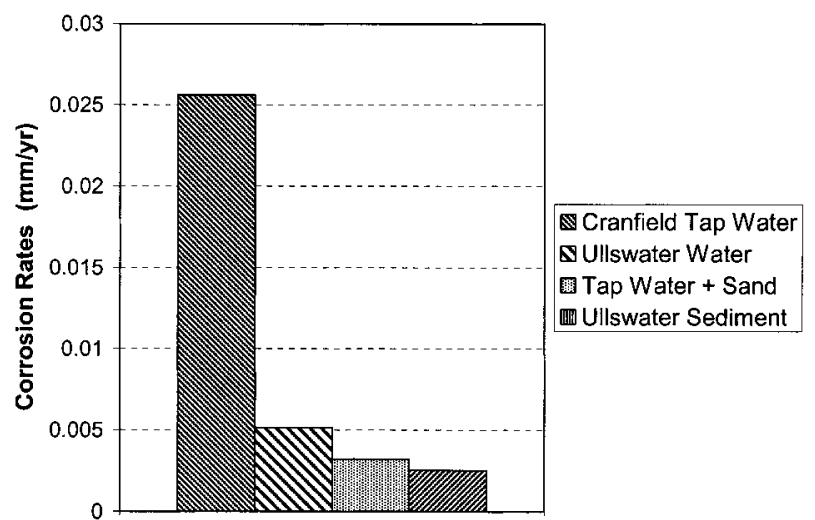

5 Comparison of corrosion rates of WI1 in tap water and Ullswater samples measured by EIS

The values of solution resistance, charge transfer resistance and corrosion rate for WI1 in tap water and water samples taken from Ullswater are summarised in Table 3 and Fig. 5. Important features of these results are the much higher values of solution resistance and charge transfer resistance measured in the water sample from Ullswater, the latter corresponding to a substantially lower corrosion rate than that in tap water. The high solution resistance was the consequence of the lower concentration of dissolved solids in the Ullswater sample, as shown in Table 4. Indeed, the conductivities of the tap water and Ullswater samples were 281 and $57 \mu \mathrm{S} \mathrm{cm}^{-1}$, respectively, giving a ratio of $4 \cdot 9: 1$. (The equivalent solution resistances of 3770 and $25100 \Omega \mathrm{cm}^{2}$ from EIS were in the ratio $1: 6 \cdot 6$, indicating quite good agreement between the two measurement methods.) It is interesting to compare the conductivity of the Ullswater sample with that measured for deionised water $\left(3 \mu \mathrm{S} \mathrm{cm}^{-1}\right)$. It is thought that the very low levels of dissolved solids in Ullswater made an important contribution to the low corrosion rate. ${ }^{11}$

Whereas burial in sand increased the solution resistance measured in tap water, for the reasons given above, burial in Ullswater sediment lowered the solution resistance. This was due to the sediment sample containing more ions than the water alone, as shown in Table 5. However, more significantly, the charge transfer resistance was higher in both Ullswater sediment and in sand, compared to the corresponding results in water alone. Therefore, in each case the corrosion rates in sediment and sand were considerably reduced. This suggests that, as the Ullswater sediment had relatively high conductivity, it was the limited access of dissolved oxygen that was the more important factor in controlling the corrosion rate of buried samples.

\begin{tabular}{|c|c|c|c|c|}
\hline \multicolumn{5}{|c|}{$\begin{array}{ll}\text { Table } 3 & \begin{array}{l}\text { Results } \\
\text { spectroscopy }\end{array}\end{array}$} \\
\hline Environ & nent & $\begin{array}{l}\text { Solution } \\
\text { resistance, } \\
\Omega \mathrm{cm}^{2}\end{array}$ & $\begin{array}{l}\text { Charge } \\
\text { transfer } \\
\text { resistance, } \\
\Omega \mathrm{cm}^{2}\end{array}$ & $\begin{array}{l}\text { Corrosion } \\
\text { rate, mm } \\
\text { year }^{-1}\end{array}$ \\
\hline \multirow{2}{*}{\multicolumn{2}{|c|}{$\begin{array}{l}\text { Cranfield tap water } \\
\text { Ullswater water }\end{array}$}} & 3770 & 6800 & 0.026 \\
\hline & & 25100 & 33700 & 0.0052 \\
\hline \multicolumn{2}{|c|}{ Tap water + sand } & 12000 & 53900 & 0.0032 \\
\hline \multicolumn{2}{|c|}{ Ullswater sediment } & 8880 & 68700 & 0.0025 \\
\hline
\end{tabular}

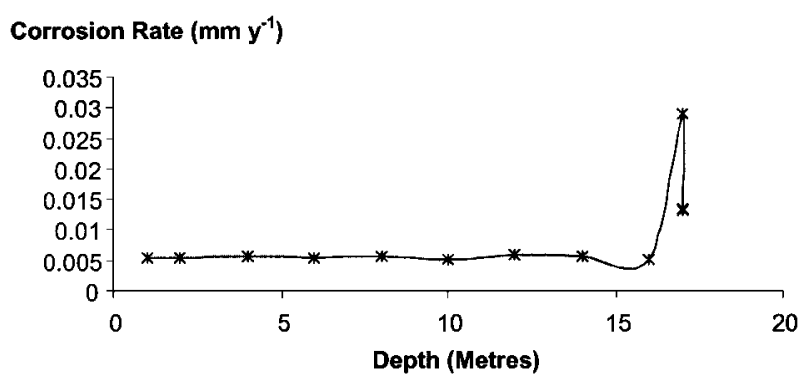

6 Effect of depth on corrosion rate of WI1 in Ullswater measured by the LPR technique

\section{Linear polarisation resistance}

The corrosion rates of WI1 measured at different depths in Ullswater are shown in Fig. 6. The LPR readings indicate that the rate was fairly constant until the corrosion probe reached the lake bed at a depth of $17 \mathrm{~m}$. The corrosion rate appeared to be higher in the sediment but this result needs further explanation, as it was influenced by the higher conductivity of the sediment, as discussed below.

A disadvantage of the LPR method is that the measured resistance includes the solution resistance of the electrolyte, which in the case of the lake water was very large. When the probe entered the sediment, the solution resistance fell, and this was interpreted as an increase in corrosion rate. A second disadvantage of the method is that the full charge transfer resistance is rarely measured, and for this reason the corrosion rate can be overestimated. In this work, the LPR measurements consisted of applying and then reversing a small dc signal to the electrodes over a total time of $4 \mathrm{~min}$. Therefore, the LPR measurement was essentially equivalent to performing an EIS experiment at a single frequency of approximately $4 \mathrm{mHz}$. This is confirmed by the close agreement between the LPR results and the impedance values at $4 \mathrm{mHz}$, as shown in Table 6. It can also be seen that the LPR and EIS results were very similar in the two water samples but that in the sand and sediment tests the LPR method overestimated the corrosion rates.

In conclusion, the in situ LPR measurements were very useful in establishing that the corrosion rate was not significantly affected by water depth in Ullswater, but they emphasise that care is needed in interpreting them in cases of high solution resistance.

Table 4 Analyses of Cranfield tap water and Ullswater sample

\begin{tabular}{|c|c|c|}
\hline \multirow[b]{2}{*}{ Parameter } & \multicolumn{2}{|l|}{ Sample } \\
\hline & $\begin{array}{l}\text { Cranfield } \\
\text { tap water }\end{array}$ & Ullswater \\
\hline $\begin{array}{l}\text { Hardness, } \mathrm{mg} \mathrm{L}^{-1} \\
\text { as } \mathrm{CaCO}_{3}\end{array}$ & 100 & 16 \\
\hline $\begin{array}{l}\text { Alkalinity, } \mathrm{mg} \mathrm{L}^{-1} \\
\text { as } \mathrm{CaCO}_{3}\end{array}$ & 50 & 34 \\
\hline $\mathrm{pH}$ & $6 \cdot 9$ & $7 \cdot 4$ \\
\hline Conductivity, $\mu \mathrm{S} \mathrm{cm}^{-1}$ & 281 & 57 \\
\hline Chloride, $\mathrm{mg} \mathrm{L}^{-1}$ & $30 \cdot 6$ & $4 \cdot 2$ \\
\hline Nitrate, $\mathrm{mg} \mathrm{L}^{-1}$ & $33 \cdot 8$ & 0.6 \\
\hline Nitrite, $\mathrm{mg} \mathrm{L}^{-1}$ & $<0.01$ & $<0.01$ \\
\hline Phosphate, mg L ${ }^{-1}$ & 0.07 & None detected \\
\hline Sulphate, $\mathrm{mg} \mathrm{L}^{-1}$ & $32 \cdot 5$ & $3 \cdot 1$ \\
\hline $\begin{array}{l}\text { Elements detected } \\
\text { (ICP-AES) }\end{array}$ & $\mathrm{Na}, \mathrm{Mg}, \mathrm{Si}, \mathrm{S}, \mathrm{Ca}$ & $\mathrm{Na}, \mathrm{Mg}, \mathrm{Ca}$ \\
\hline
\end{tabular}




\section{Expected long term corrosion rate in Ullswater}

The effect of long term exposure of wrought iron in Ullswater can be estimated from a combination of the results of the weight loss and EIS experiments. The weight loss measurements had the inherent advantage of a longer exposure time, during which corrosion products developed, producing surface conditions more representative of those on Dolly's boiler. For practical reasons, weight loss tests were carried out in tap water alone, but the EIS measurements provided a valuable comparison of the corrosion rates over the full range of tap water and Ullswater conditions.

When rediscovered in 1960, Dolly's boiler was reported by the divers to have been visible and covered with just a thin layer of silt. ${ }^{12,13}$ Therefore, the corrosion rate measured in the weight loss tests on buried samples appears to be the most appropriate, although it could be argued that the stagnant water tests were also applicable. The rate for WI1 buried in sand and tap water was $0.039 \mathrm{~mm} \mathrm{year}^{-1}$ (Fig. 2). As the corrosion rate in Ullswater sediment from EIS measurements was $78 \%$ of that in sand and tap water (Table 3), the expected weight loss value in Ullswater sediment would be $0.030 \mathrm{~mm}_{\text {year }}{ }^{-1}$.

Alternatively, if the boiler is considered to have lain in essentially stagnant water, rather than having been buried, then the appropriate corrosion rate from weight loss measurements will be $0.086 \mathrm{~mm}_{\text {year }}{ }^{-1}$. A comparison of the corrosion rates in tap water and Ullswater yields an expected corrosion rate in stagnant Ullswater conditions of $0.018 \mathrm{~mm} \mathrm{year}^{-1}$. It is reasonable to conclude that the corrosion rate of WI1 would have been in the range $0 \cdot 018-0.030 \mathrm{~mm}_{\text {year }}{ }^{-1}$. Over the 67 years for which Dolly was submerged, this would represent a metal loss of $1 \cdot 2-2 \cdot 0 \mathrm{~mm}$. It is thought unlikely that this metal loss would have been exceeded, as the progressive formation of thicker and more protective corrosion products would be expected to have reduced the long term corrosion rate.

\section{Observed metal loss on Dolly's boiler}

The condition of the shell of the boiler (horizontal return firetube design) suggests that a metal loss of 1$2 \mathrm{~mm}$ on the external surface is reasonable. However, the original wall thickness is unknown (probably 10$12 \mathrm{~mm}$ ), so it is difficult to be certain on this point. Ultrasonic thickness measurements were carried out to compare the wall thickness in different regions, and the firebox crown, which had been subject to direct heating during Dolly's working life, was shown to have the lowest metal thickness. ${ }^{13}$ Parts of the lower shell that had rested on a brickwork base were externally pitted, probably because of differential aeration cells during submersion. Otherwise, the wall thickness was quite uniform. (The boiler was reported to have been empty

Table 5 Analysis of Ullswater sediment

\begin{tabular}{lll}
\hline $\begin{array}{l}\text { Solids } \\
\text { content, } \\
\text { mg L }^{-1}\end{array}$ & $\begin{array}{l}\text { Elements } \\
\text { detected } \\
\text { (ICPAES) }\end{array}$ & $\begin{array}{l}\text { Sulphate } \\
\text { reducing } \\
\text { bacteria }\end{array}$ \\
\hline 30000 & $\mathrm{~B}, \mathrm{Na}, \mathrm{Mg}, \mathrm{Al}$, & $<10$ colony \\
& $\mathrm{Si}, \mathrm{P}, \mathrm{S}, \mathrm{K}, \mathrm{Ca}$, & forming units $\mathrm{mL}^{-1}$ \\
& $\mathrm{Ti}, \mathrm{V}, \mathrm{Mn}, \mathrm{Fe}$, & \\
& $\mathrm{Cu}, \mathrm{Zn}, \mathrm{As}, \mathrm{Sr}$, & \\
$\mathrm{Cd}, \mathrm{Sb}, \mathrm{Ba}, \mathrm{Pt}, \mathrm{Pb}$ & \\
\hline
\end{tabular}

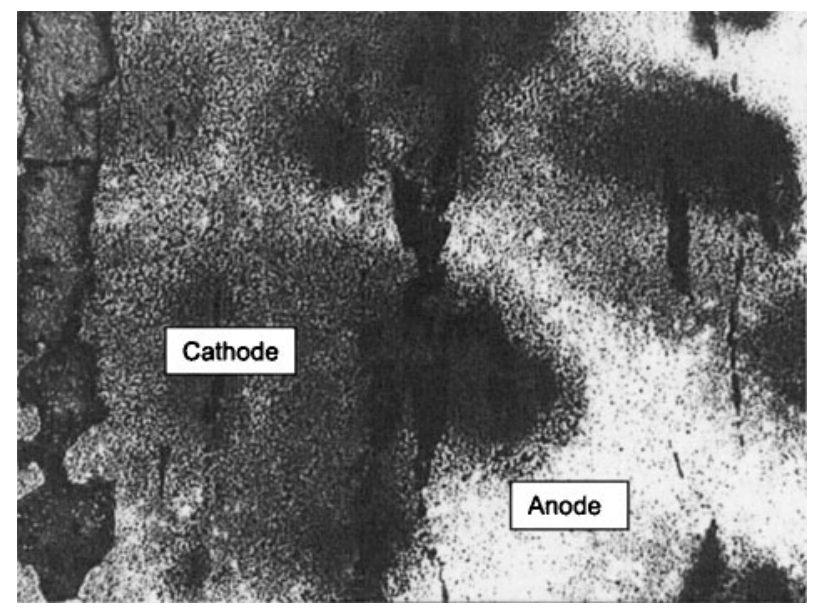

7 Formation of corrosion products at cathodic sites associated with slag inclusions on WI1 after $30 \mathrm{~min}$ in tap water

when Dolly was recovered, ${ }^{14}$ so internal corrosion can be disregarded.)

\section{Effect of water analysis}

The Ullswater sample was similar to Cranfield tap water (Table 4), and confidence can be placed in the validity and relevance of the weight loss measurements performed in tap water. The Ullswater sample is classed as soft water, while Cranfield tap water is moderately soft/ slightly hard. They have similar $\mathrm{pH}$ values and both have negative Langelier indices, ${ }^{5}$ indicating that they are non-scale forming.

While heavy metals were found in the lakebed sediment (Table 5), these are thought to have been bound up in stable compounds, as extraction in an acid was required in order to analyse them by Inductively Coupled Plasma Atomic Emission Spectroscopy (ICPAES). No heavy metal ions were detected in the water sample and they are not thought to have contributed to the corrosion rate by plating onto the metal surface. The low corrosion rates measured in the lake suggest that microbially influenced corrosion was not a factor in the boiler corrosion. This was confirmed by the low number of sulphate reducing bacteria detected in the lakebed sediment $(<10$ colony forming units $\mathrm{mL}^{-1}$ ).

\section{Influence of slag inclusions}

The slag inclusions were shown to be cathodic to the ferrite grains in both wrought iron materials tested. Polished samples were immersed in tap water and removed at intervals for examination under an optical microscope. It was found that corrosion products formed first in areas close to the slag inclusions, as

Table 6 Comparison of LPR values with EIS values at $4 \mathrm{mHz}$ and charge transfer resistances

\begin{tabular}{|c|c|c|c|}
\hline Environment & $\begin{array}{l}\text { Linear } \\
\text { polarisation } \\
\text { resistance, } \\
\Omega \mathrm{cm}^{2}\end{array}$ & $\begin{array}{l}\text { Impedance } \\
\text { at } 4 \mathrm{mHz} \\
\Omega \mathrm{cm}^{2}\end{array}$ & $\begin{array}{l}\text { Charge } \\
\text { transfer } \\
\text { resistance, } \\
\Omega \mathrm{cm}^{2}\end{array}$ \\
\hline Cranfield tap water & 6772 & 6928 & 6801 \\
\hline Ullswater water & 29848 & 29000 & 33656 \\
\hline Tap water + sand & 17141 & 18645 & 53906 \\
\hline Ullswater sediment & 13068 & 13333 & 68742 \\
\hline
\end{tabular}


shown in Fig. 7. This identified the inclusions as cathodic sites, as it was the $\mathrm{pH}$ increase associated with the cathodic reaction that caused the precipitation of iron hydroxide. The galvanic interaction between the slag inclusions and adjacent ferrite grains would be expected to have caused high corrosion rates. However, it appears that the exposed inclusions were sufficiently small in area for the acceleration of corrosion to be fairly insignificant.

Balasubramaniam $^{2}$ proposed that the cathodic reaction on the slag inclusions in wrought iron could exceed the critical current density required to passivate the anodic ferrite, thus reducing the corrosion rate. $\mathrm{He}$ attributed the corrosion resistance of the Delhi iron pillar partly to this effect, as the iron has a high phosphorus content, which promotes passivity, and partly to the wetting and drying conditions that led to the formation of adherent, non-porous corrosion products. It is not evident that the wrought irons investigated in the present study behaved in this way, as they did not contain significant phosphorus in the ferrite, and when they were tested in fully immersed conditions their corrosion rates differed little from that of carbon steel.

\section{Conclusions}

1. There were two principal causes for the low corrosion rate of Dolly's wrought iron boiler in Ullswater. The first was the low oxygen content of the water at the lake bed, particularly beneath the thin layer of silt that had collected on the boiler's surface. The second cause was the low conductivity of the lake water, which had a composition similar to that of rain water and contained only small concentrations of dissolved solids.

2. The corrosion rate of wrought iron in the lakebed environment is estimated to be in the range 0.018 $0.030 \mathrm{~mm}$ year $^{-1}$, which corresponds to a metal loss of $1 \cdot 2-2 \cdot 0 \mathrm{~mm}$ over the 67 years for which Dolly was submerged. Weight loss measurements in water and sediment environments showed that the corrosion rates of wrought iron did not differ greatly from those of modern boiler steel.

3. Slag inclusions in the wrought iron were shown to be cathodic to the ferrite grains but the relatively small areas of the inclusions meant that the corrosion rate was not accelerated significantly. The possible effects of heavy metals and microbial activity in the sediment were considered, but they are not thought to have contributed to the corrosion behaviour of the boiler.

\section{Acknowledgement}

The authors are grateful for assistance provided by the Windermere Steamboats Museum, Cumbria, where SL Dolly is displayed.

\section{References}

1. Windermere Nautical Trust: 'Salvage of steam launch Dolly'; 1979, Kendal, Titus Wilson.

2. R. Balasubramaniam: Corrosion Sci., 2000, 42, 2103-2129.

3. National Association Of Corrosion Engineers: 'NACE-8, Biologically induced corrosion', (ed. S. C. Dexter); 1986, Houston, TX, NACE.

4. J. F. D. Stott: Corrosion Sci., 1993, 35, 667-673.

5. C. W. Drane: in 'Corrosion', (ed. L. L. Shreir), Vol. 1, 2nd edn, 2:38-2:50; 1976, London, Newnes-Butterworths.

6. W. T. Shaw: 'Mining in the lake counties'; 1970, Clapham, Dalesman.

7. American Society For Testing Materials: 'Preparing, cleaning and evaluating corrosion test specimens', ASTM G1; 1999, Philadelphia, PA, ASTM.

8. L. L. Shreir and F. L. Laque: in 'Corrosion', (ed. L. L. Shreir), Vol. 2, 2nd edn, 20:3-20:108; London, Newnes-Butterworths.

9. National Association Of Corrosion Engineers: 'Corrosion engineer's reference book', (ed. R. Baboian), 3rd edn, 151-152; 2002, Houston, TX, NACE International.

10. G. W. Walter: Corrosion Sci., 1986, 26, 681-703.

11. M. G. Fontana: 'Corrosion engineering', 3rd edn, 381; 1987, London, McGraw-Hill.

12. P. Carter: Personal communication.

13. I. A. Turnbull: 'Investigation of boiler corrosion on the historic vessel S.L. Dolly', MSc thesis, Cranfield University, 2004.

14. Windermere Steamboats Museum: Archive material on Dolly's recovery and restoration. 